\title{
A Development of Students' Worksheet Based on Contextual Teaching and Learning
}

\author{
Dr. Zulyadaini, M.Pd ${ }^{1}$ \\ University of Batanghari Jambi
}

\begin{abstract}
This research is aimed at developing the students' worksheet to determine the quality of validity and practicality aspects based on expert's assessment of materials, expert's design, media specialists, an individual assessment of students' testing, a small group assessment of students trial, and a field trials assessment of students.This study is adapted from the development of ADDIE model which consists of 5 stages: 1) Analysis, 2) design, 3) Development, 4) Implementation, and 5) evaluation. The results showed that the quality of students' worksheet of mathematics on materials of factorization in algebra-based on Contextual Teaching and Learning basically on the assessment of: 1) the experts' of subject materials is obtained a total average of 3.81 is included in the category of "Good" or scored $76.2 \%$ which is included in the category of "Very Decent", 2) the experts' design is obtained a total average of 3.62 which is included in the category of "Good" or scored 72.4\% which is included in the category "Decent", 3) the experts' of media is obtained scored 4:43 which is included in the category of "Good" or scored 88.6\% which is in the category of "Very Decent". Whereas, the assessment by the students is done in three stages: 1) an individual assessment of students' testing is obtained average total of 4.75 which is included in the category of "Very Good" or 95\% which is included in the category of "Very Decent", 2) a small group assessment of students trial is obtained total average of 4:58 which is included in the category of "Very Good" or scored 91.6\% thus it is included in the category of "Very Decent", 3) a field trials assessment of students is obtained a total average of 4:43 which is included in the category of "Very Good" or scored $88.6 \%$ thus it is included in the category of "Very Decent". Thus mathematics on materials of factorization in algebra-based on Contextual Teaching and Learning $(C T L)$ is declared valid and practical so it can be used as the learning equipment of mathematics at the factorization material algebra.
\end{abstract}

Keywords: Development, students' worksheet, CTL, ADDIE

\section{Introduction}

Mathematics is a subject that is learnt at all levels of education in Indonesia it is started from primary school level to university level. Through the study of mathematics, the students will learn how to give reason critically, creatively and actively. Because mathematics is abstract ideas that contain symbols, so the mathematical concept must be understood first before manipulating symbols. But many students face some difficulties in learning mathematics. According to Wittgenstein (Hasratuddin, 2014: 30) mathematics is a way to find answers to the problems faced by humanity, such as a way to use the information, using the knowledge of propagating shape and size, using the knowledge of the counting and the most important thing is thinking about the inside-self of human being and using its connections. Mathematics is one of the disciplines that can improve the ability to think and argue, give a great contribution in solving everyday problems in workplace, as well as to provide support in the development of science and technology (Susanto, 2013: 185).

The process of learning mathematics in every level of education is very important, therefore it is necessary to have fun to realize the role of teachers in the implementation of the learning process to realize the goal of learning mathematics. To have a fun learning process in the classroom, it is required an innovative teaching materials. One of the teaching materials used by teachers to support the learning process is students' worksheet.Students' worksheet is one of the printed materials (other than handouts, modules and books) that can be used in the teaching and learning process. Through the use of students' worksheet, teachers have a chance to lure the students to actively engage with the material learnt in the classroom (Prastowo, 2015: 399). Students' worksheet contains a set of basic activities that must be performed by students in an effort to maximize the understanding of the formation of basic capabilities of the students in corresponding indicators of achievement of learning outcomes that must be taken. Students' worksheet is the efforts of teachers to guide students in a structured way, which the activities are giving an incentive for the students to learn mathematics. It has already known that the teachers are required to complete their duties and their roles are no longer as informants of the knowledge but their roles should be as a motivator in the process of teaching and learning so that students can construct their own knowledge through various activities in the learning activities. Through the use of the students' worksheets in the learning process, the students are expected to learn a subject matter independently. One of the efforts to improve the students' quality in learning mathematics, the students should improve the quality of learning. According to Fajar Sadiq (Setiawan, 2010: 1) one of a growing trend of mathematics 
education in the world today is the shift in mathematics education from formal shape to its application, processes of activities, and problem solving in a real situation. In other words it is a process from deductive to inductive. One of the models that can be applied to these demands is Contextual Teaching and Learning.

Rusman (2014: 188) states that the core of CTL is the linkage of any content or subject of learning to real life. To relate CTL could be done in various ways, as it relates to the factual conditions or a real-life experience. Thus, Contextual Teaching and Learning will be more attractive in the classroom as the students perceive the benefits of teaching and learning through Contextual Teaching and Learning.

With this concept, Contextual Teaching and Learning is a suitable model when applied in teaching materials of algebra factorization. This is because the rate of algebra factorization is the material that is associated with the factual situation, although in teaching and learning process it is often used as symbols to represent the factual situation. Similarly, CTL model which is also a concept of study that links between what is taught in the classroom with the real-world situations, it is also involving seven major components of effective learning, they are constructivism, questioning, inquiry, learning community, modeling, reflection, and authentic assessment.Based on these problems, the researcher is interested in developing teaching materials in the form of Student Worksheet which is based on Contextual Teaching and Learning on the material algebra factorization. Students' Worksheets based on CTL for the material of algebra factorization rate which corresponds to the characteristics of the students, the social environment of students, that could enable the students' motivation in learning mathematics. The Students' Worksheets which is meant in this study is the development of teaching materials that is oriented on the appearance of problems related to real life. Context issues raised must be in accordance with the concept of the material being studied in the classroom. Context is meant situations or events in accordance with the concept being studied. The students' worksheets which is based on CTL for the materials of algebra factorization could help students understand the usefulness of the material of algebra factorization algebra in the real life.

\section{Research Methodology}

This study is a Research and Development (R \& D). Sugiyono (2014: 333) argues that, methods of research and development is the research methods used to produce a specific product and test the effectiveness of the product. In this study, the results of the product is in the form of teaching materials in the form of Students' Worksheet (LKS) which is based on Contextual Teaching and Learning (CTL) on the material of Form Algebra Factoring for Junior High School students of Grade VIII. The Students' Worksheet which is based on the development of Contextual Teaching and Learning (CTL) on the material of algebra factorization follows the ADDIE model. ADDIE Model consists of five steps, namely: (1) analysis, (2) design, (3) development, (4) implementation, (5) evaluation.

\section{Data Collection}

\section{Data And Discussion}

The Students' Worksheet was the result of early development which is then continues to the validation phase by the experts. The purpose of the validation phase is to look at the quality of the students' worksheet based on the aspects of validity. At this stage, the students' worksheet was validated by two experts which are expertise on design and one media. These two experts were provided on comments, suggestions, and assessment of the products. Comments, suggestions and assessment of subject matter experts, expert design and media experts were taken as the basis for revising the previous product of the students' worksheet in order to get a better product. The following explanations and charts the results of the experts' valuation and analysis.

\section{a) The expert of Content}

Based on an expert assessment by the overall material the students' worksheet gets a total score of 80 with an average of 3.81 which is included as "Good" category. While it is calculated by percentage the students' worksheet gets $76.2 \%$ which is included as "Sufficient" category.

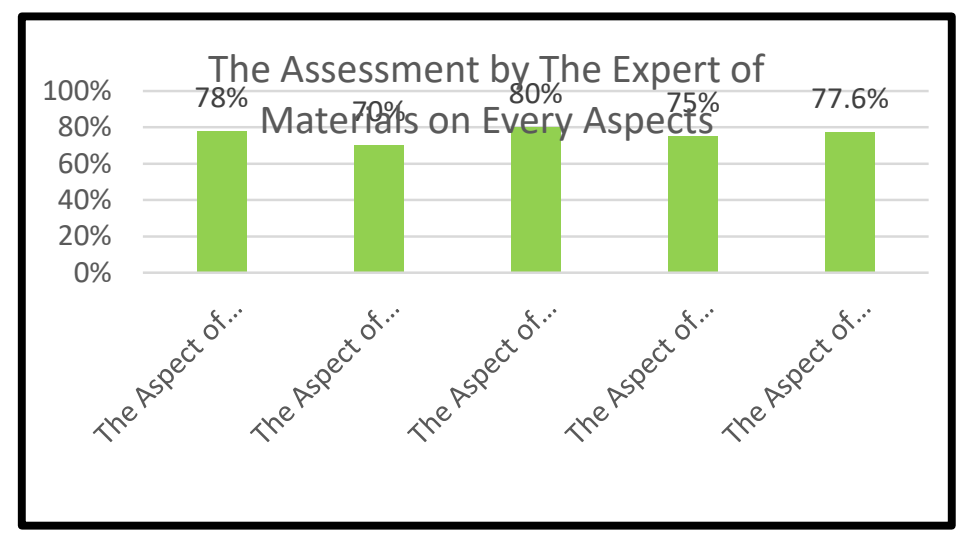

Figure 1: Percentage Rate by Expert of Content on Every Aspect 
Based on the chart above it can be seen that the percentage of eligibility of the students' worksheet by the expert of materials there is a highest feasibility of its material which is percentage to $80 \%$ (first rank), the second rank is the aspect of the precision of the content by with its percentage of $78 \%$, the third rank is the aspect of the completeness of the component with its percentage of $77.60 \%$, the fourth rank is the aspect of language used in the students' worksheet with its percentage of $75 \%$, and the fifth rank is the aspect of coverage accuracy of the content by percentage of $70 \%$. The experts' results of the assessment on the materials in all aspects of the assessment are in the category of a "Decent" and "Very Decent". Based on the results of these assessments, the quality of the students" worksheet materials is declared as "Valid".

\section{b. The Expert of Design}

Based on the experts' assessment the overall design of the students' worksheet gets a total score of 47 with an average of 3.62 which is included as "Good" category. While it is calculated by percentage the students' worksheet gets $72.4 \%$ which is included as "Eligible" category to be used as a teaching and learning material in the classroom.

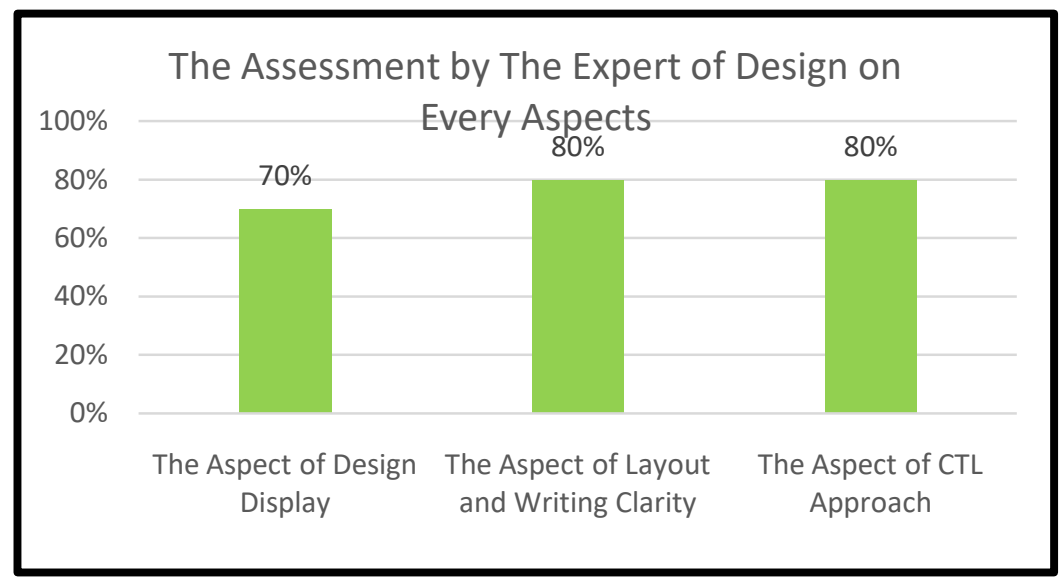

Figure 2: Percentage Rate by the Experts of Design in Every Aspect

Based on the above chart it can be seen that the percentage of eligibility of the students' worksheet the highest rank is on the CTL approach aspects, the aspects of the layout, and the clarity of writing which are equal to $80 \%$ and the lowest rank are in the aspect of layout and the clarity of the text with a percentage of $70 \%$. The results of the assessment have been done by the design experts on all aspects of the assessment are in the category of a "Decent" and "Very Decent". Based on the results of these assessments, the design of the students' worksheet quality is declared as "Valid".

\section{c. The Expert of Media}

Based on the experts' assessment the overall design of the students' worksheet gets a total score of 102 with an average of 4.43 which is included as "Good" category. While it is calculated by percentage the students' worksheet gets $88.6 \%$ which is included as "Very Feasible" category to be used as a teaching and learning material in the classroom.

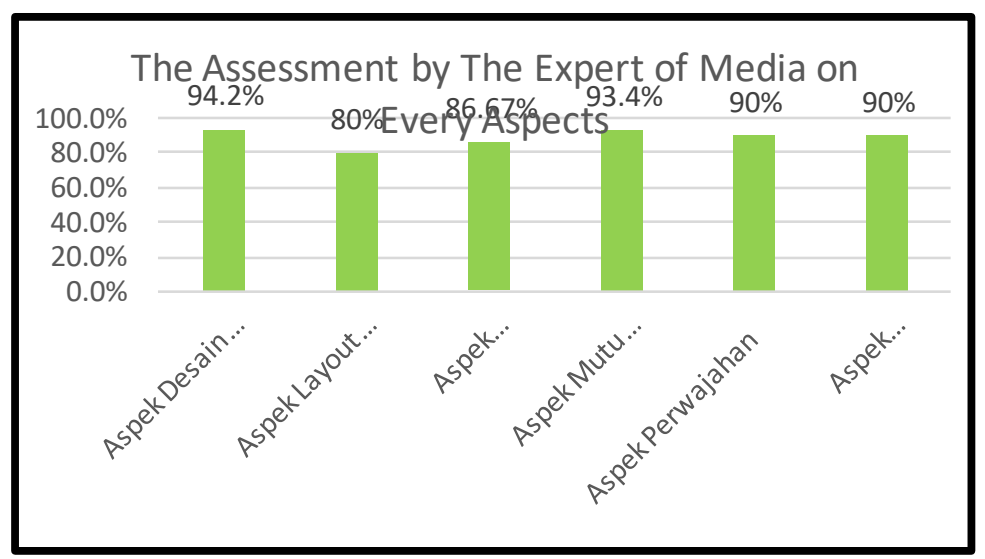

Figure 3: Percentage Rate by the Experts of Media in Every Aspect 
Based on the chart above it can be seen that the percentage of eligibility of the students' worksheet gets the highest rank in the design aspects of the display which is equal to $94.2 \%$, the second rank is the aspect of picture quality with a percentage of $93.4 \%$, the third rank is the aspect of the appearance and the aspect of completeness of the component by a percentage by $90 \%$, the next rank with a percentage of $86.67 \%$ is on the aspects of font usage, and the last rank are the aspects of the layout and the aspect of layout with a percentage of $80 \%$. The results of the assessment have been done the experts of media in all aspects of the assessment are in the category of a "Decent" and "Very Decent". Based on the results of these assessments, the quality of the students" worksheet on its media is declared as "Valid".

Based on the results of recapitulation above, it is known that the individual testing gained an average of 4.75 so that the total is included in the criteria "Very Well". Eligibility of the Students' Worksheet is included in the category of "Very Decent" with a percentage of 95\% was obtained. In addition to the analysis of overall score it can also be known the students' worksheet assessment every aspect. The aspects questionnaire individual assessment testing includes aspects of design display, aspects of size and fond character, aspects of the layout, the aspect of clarity of learning objectives and instructions for using the students' worksheets, the aspect of clarity, aspects of the suitability of the picture, the aspect of suitability image and exercise, as well as aspects systematically.

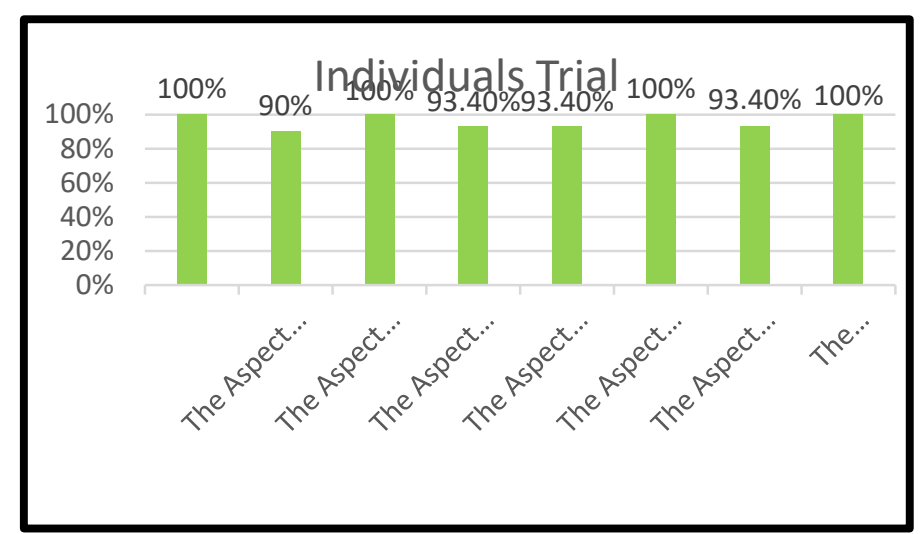

Figure 4: Percentage on Every Aspect of Individual Trial

\section{Small group Trial}

Based on the results of recapitulation it is known that the small group trial consists of 6 students who have the ability category to high, medium, and low, it is obtained an average total score is 4:58 which is included in the criteria of "Very Well". Eligibility of the Students' Worksheet is included in the category of "Very Decent" with a percentage of $91.6 \%$.

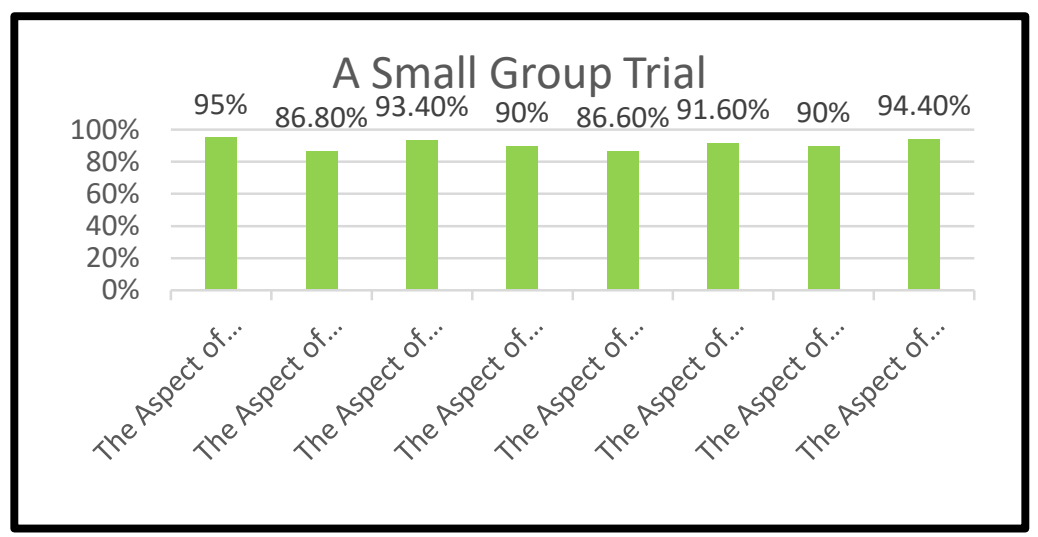

Figure 5: Percentage on Every Aspect of Small Group Trial

\section{Field Trial}

Field trial was conducted on 23 students in one classroom students. Field trial was conducted to look at the quality of the students' worksheet based on aspects of practicality. In this phase the students were given the worksheet which is designed by the researcher for the learning materials. After using this worksheet, the next phase was that the students were given questionnaire to assess the students' worksheet. The questionnaire consists of 13 statements based no 1 to 5 scale. The scale category is (1) for "Less", (2) is "less", (3) is

DOI: $10.9790 / 5728-1301033038 \quad$ www.iosrjournals.org $33 \mid$ Page


"enough", (4) is "good" and (5) was "excellent". The subject of field test was the eighth grade student was obtained an average total score is $4: 43$ which is included in the criteria "Very Well". Eligibility of the Students' Worksheet is included in the category of "Very Decent" with a percentage of $88.6 \%$. In addition to the analysis of overall score it can also be known that the students' worksheet assessment from every aspect. The field trials aspects of assessment in questionnaire consists of the presentation of the material aspect, aspects of relevance to everyday life, aspects of the concept of conformity with the purpose of learning, aspects of language use, CTL approach aspects, aspects of information and the students worksheet aspect of existence.

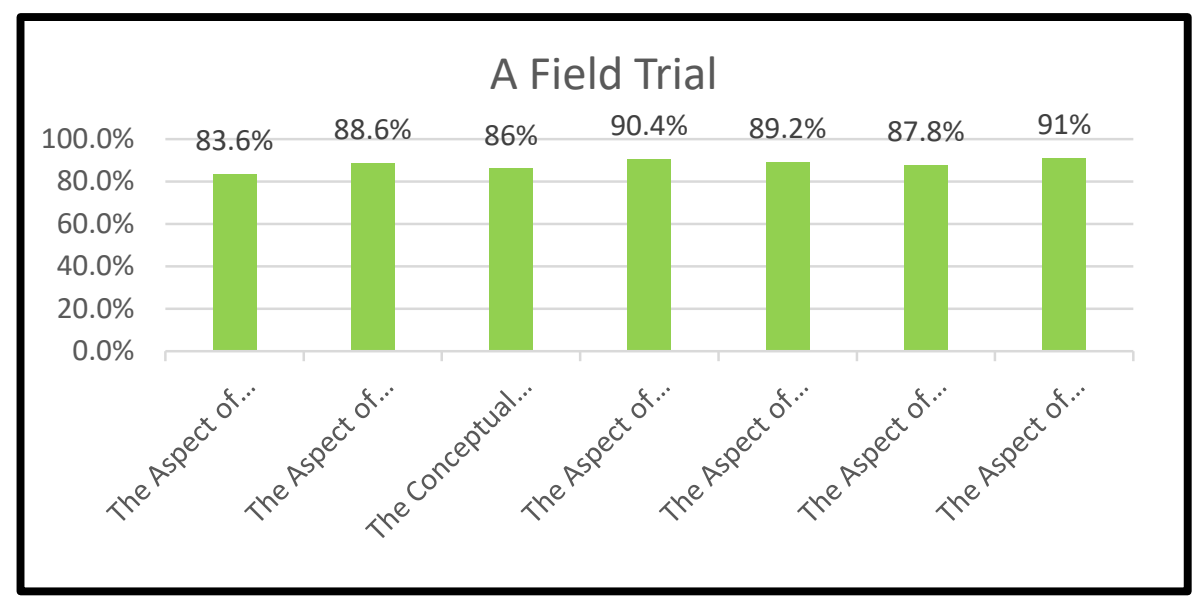

Figure 6: Percentage in Every Aspect of Field Trial

Results of assessment of students on field trials of all aspects of assessment are in the category of a "Decent" and "Very Decent". Based on the results of these assessments, the quality of the students' worksheet is declared as "practical".

\section{Evaluation}

The last step is to evaluate the students' worksheet on the subjects of algebra factorization which have been developed based on the results of expert's assessment sheets of material, the experts of design, the experts of media, individual testing, small group trial and field trials. The results of the evaluation are as follows:

\section{Expert of Content}

Based on the recapitulation of the students' worksheet which was validated by the subject matter experts obtained an average score of 3.81 which is included in "Good" categories. While is calculated by percentage it is found $76.2 \%$ of the students" worksheet which is included in the category of "Very Feasible" to be used in the classroom as a learning material. Based on the results of these assessments, the quality of the students' worksheet is declared as "Valid". The revisions of the students' worksheet have been done based on based on the recommendations of the subject matter experts. The recommendations are (1) Eliminating of all the images in the answer box and the conclusion box in the students' worksheet, (2) Adding the assessment criteria and the way of processing the score resulting from the appraisal process on the authentic assessment sheet. Then the revisions of the students' worksheet based on the recommendation of the subject matter experts has been done with their recommendations are (1) Changing the item of number 3 which was previously "How is the length and width of Angga's durian garden? Please answer the question in algebraic formulation. It is changed into "How is the length and the width of Budi's rambutan garden? Please answer the question in algebraic formulation, (2) Adding the activity on the material of algebra multiplication into two activities. The first activity is related to multiplying a number by algebraic binomial form and the second activity is associated with the multiplication rate of two, (3) Changing the item of distribution on activities 5 into a division item which is simpler, (4) Changing the Question of number 4 on an individual exercise become more simpler division item.

\section{The Expert of Design}

Based on the recapitulation of the students' worksheet validation which was done by the expert of design obtained an average score of 3.62 that is included in "Good" category. While it is calculated by percentage $72.4 \%$ it is included in the category "Eligible" to be used as a learning material in the classroom. Based on the results of these assessments the quality of the students' worksheet is declared as "Valid".

The revisions of the students' worksheet was made based on the recommendation of the expert of subject matter as follows (1) Changing the picture junior high school students on the cover with a picture of formula, 
multiplication and factoring algebraic form, activity in the market, and people who are measuring the road, (2) Changing the phrase of "content-based Standard" to "Competence-based standard" and provide numbering using the letters on the table of contents, (3) Changing the overall instructions for using worksheets into a description of the image that is in worksheets and explanations concerning the application of seven components Contextual Teaching and Learning (CTL) which contained in the students' worksheet, (4) Adding the remarks of component in all parts of the students' worksheet, (5) Replacing the column of "SCIENCE" becomes keywords which is listed in the beginning of section of the students' worksheet, (6) Changing the color column becomes a white color to be simpler, (6) Making the boxes empty with blank spaces in order to make easy the students in answering the questions.

\section{Expert Media}

Based on the recapitulation of the students' worksheet validation which was done by the expert of media obtained an average score of $4: 43$ that is included in "Good" category. While it is calculated by percentage $88.6 \%$ it is included in the category "Eligible" to be used as a learning material in the classroom. Based on the results of these assessments the quality of the students' worksheet is declared as "Valid".

\section{Individual Trial}

Based on the recapitulation of the evaluation worksheets on individual testing of three eighth grade students and it is found an average score of 4.75 which is included in the "Excellent" category. While it is calculated by percentage the students" worksheet gets $95 \%$ thus included in the category of "Very Feasible" to be used as a learning material in the classroom. Based on the result of the individual trial there is no revision on the students' worksheets.

\section{Trial Small Group}

Based on the recapitulation of the evaluation worksheets in small group trial of six eighth grade students and it is found an average score of 4:58 which is included in the "Excellent" category. While it is calculated by percentage the students' worksheet gets $91.6 \%$ which is included in the category of "Very Feasible" to be used as a learning material in the classroom. Based on the result of the small group trial there is no revision on the students' worksheets.

\section{Field Trial}

Based on the results of the evaluation recapitulation of the students' worksheet in field trials of 23 students in one classroom of the eight it is obtained an average score of 4:43 which is included in the "Excellent" category. While it is calculated by percentage it is found $88.6 \%$ of the students' worksheet which is included in the category of "Very Feasible" to be used as a learning material in the classroom. Based on the result of these assessments the quality of the students' worksheet is claimed as "Practical". Based on the result of the small group trial there is no revision on the students' worksheets.

\section{Discussion}

Development of Student Worksheet (LKS) based on Contextual Teaching and Learning on the material of algebra factorization which is developed by using ADDIE development model. ADDIE Stages include: 1) Analysis, 2) Design, 3) Development, 4) Implementation and 5) Evaluation. The development phase begins with the analysis which includes competency analysis, analysis of student characteristics, and analysis of the material. At this stage the researcher tries to find out the problems that causes of the low results of Mathematics subject at SMPN 9 Muaro. After conducting observation by interviewing one of the mathematics teachers in the eight grade and it is found that one of the causes of the problem lies in the students worksheets used in the classroom. The students' worksheet used in the classroom by students is only contains the material and the questions that are still monotonous. The content of the students worksheet is presented briefly and using instruction of the language that is difficult to comprehend by the students. It is resulting to the students' motivation in learning the material of algebra factorization. The examples and practices used in the students' worksheet is only symbolic and there is no correlation between the material of algebra factorization to students' daily lives. The heavy use of mathematical symbols in the material of algebra factorization makes the students tend to memorizing all these symbols without deeper understanding on the actual concept of learning algebra factorization. Based on the case study above the researcher decided to develop a students' worksheet based on Contextual Teaching and Learning on the material algebra factorization. The next stage is designing of the product. In this step the researcher collected information related to the development the students' worksheet such as collecting books and sources on the material of algebra factorization. Designing of the basic framework of the students' worksheet and drawing up the assessment sheet of the products. 
The next stage is developing of the product. In this step the researcher developed the product through several measurements such as (1) arranging the students' worksheets based on the Standard of Competency, the Basic Competency, the Learning Objectives and Learning Indicators on the material of algebra factorization, (2) arranging the materials, (3) determining the assessment tools, and (4) paying more attention on the structure of the students' worksheet including the title, the standard of competency, the basic competence, learning indicators, learning objectives, maps conception, tasks and exercises, as well as assessment. After constructing of the students' worksheet the next stage was conducting a product validation. The product validation was conducted by two experts of design and media. The purpose of validation is to see the quality of the students' worksheets based on the aspect of validity. The first validation was done by a subject matter expert. In this process of validation the expert conducted assessment on the questionnaires. Questionnaire for subject matter experts composed of five aspects, namely the precision of the content, accuracy aspects of the scope, the content, aspect of understanding, the aspects of the use of language and the aspects of completeness of the component.

After being revised by the experts further assessment was made by the expert of design. In this validation process the experts assessed on the questionnaire that has been provided. Questionnaire for the expert of design consists of three aspects, namely the aspect of display design, layout and clarity of the writing aspect as well as the aspects of CTL component. After being revised by the experts further assessment was conducted by the experts of media. In this validation process the expert assessed on the assessment tools of the questionnaire that has been provided. Questionnaire for expert of media consists of six aspects, namely the aspect of display design, layout and layout, the aspects of font usage, the aspect of image quality aspects, the aspects of the appearance and the aspect of completeness of the component.

The next stage is the implementation of the product. In this stage the revised students' worksheets based on the assessment of the experts have to be tested. The trial was conducted to determine the quality of the students' worksheet based on the aspects of practicality. The test was done in three stages, namely individual testing, small group trial and field trials (field try-out). The next stage is a small group trial. The object of this field trial was 6 students of the eight grades who have different learning ability of high, medium and low. The assessment was conducted on the mathematics classroom. Researcher asked students as respondents to provide an assessment of the students' worksheet by filling out a questionnaire that has been provided. The questionnaire used consisted of 15 statements. The next stage is a field trial. This stage is the last stage in the assessment process of the students' worksheet. The object of the field trial was 23 students form one class of the eight grades. At this stage the students' worksheet has been completely revised and used in the learning process. Then the researcher asked the students to give an assessment of the students' worksheet by filling out a questionnaire that has been provided. The questionnaire used consisted of 13 statements. The purpose of the field trial is to look at the quality of the students' worksheet based on the aspects of practicality.

The last stage of research and development is evaluation. The evaluation was conducted to collect data on the phases of the students' worksheet. The data were obtained as follows:

1. The assessment was conducted by the expert of subject matter of the students' worksheet get an average total of 3.81 which were included in the rating categories of "Good" and if it is presented $76.2 \%$ thus included in the category of "Very Decent". Thus the students' worksheet d is declared "Eligible" based on an assessment in terms of material. Based on the result of this assessment the quality of the students' worksheet is as "Valid".

2. The assessment was conducted by the expert of design gets total score of 3.62 is included in the rating categories "Good" and if it is presented $72.4 \%$ that was included in the category of "Eligible". Thus the students' worksheet is declared "Eligible" based on an assessment in terms of design. Based on the results of these assessments the quality of the students' worksheet is declared as "Valid".

3. The assessment was conducted by the expert of media gets an average total of 4:43 which is included in the assessment categories of "Good" and if it is presented $8.6 \%$ that is included in the category of "Very Decent". Thus the students' worksheet is "Very Worthy" to be applied in the classroom. Based on the results of these assessments the quality of the students" worksheet is declared as "Valid".

4. The results of individual testing obtained an average total of 4.75 which is included in the category ratings "Very Good" and if it is presented $95 \%$ that is included in the category of "Very Decent".

5. The results of the small group trial gets an average total of 4:58 which is included in the category ratings "Very Good" and if it is presented $91.6 \%$ thus it is included in the category of "Very Decent".

6. The results of field trials gets an average total of 4:43 which is included in the category ratings "Very Good" and if it is presented $88.6 \%$ thus it is included in the category of "Very Decent". Based on the results of these assessments the quality of the students' worksheet is declared "Practical".

Based on the results of the assessment conducted by experts and the students, mathematics worksheets based on CTL of the material of algebra factorization is suitable for using in a teaching and learning tool of mathematics. 
The Limitations of the study:

\section{The Limitation Of The Research}

1. The costs on research and development is expensive.

2. The Students' Worksheet generated in this research is only a first level of development which consists of the material of algebra factorization.

3. Test implementation and evaluation of the students' worksheet is only performed on one state junior high school that is SMPN 9 in Muaro Jambi Regency.

4. The quality of the students' worksheet of this research is only seen in the aspect of validity and practicality.

\section{Conclusions And Recommendations}

Based on the results and discussions above the researcher can conclude the following conclusions:

1. Development of the Students' Worksheet based on Contextual Teaching and Learning on the material of Algebra factorization using ADDIE model which includes five stages of development, namely:

\section{a. Analysis}

- Analytical of competency

The results of the analytical competency relates to curriculum, standard competency, Basic Competency and indicators of learning as well as the time allocation of the material of algebra factorization to be published in the form of students' worksheets learning device.

- Analysis of the students' characteristics

The analytical of the students' characteristics is obtained from interviews to teachers of mathematics of the eight grades of SMPN 9 Muaro Jambi Regency. From the results of these interviews showed that the learning outcome of mathematics subject of the algebra material is still low. This is because students have difficulty in understanding the material. The heavy use of mathematical symbols in the material of algebra factorization algebra makes the students tend to merely memorizing these symbols without deeper understanding the actual concept in learning the material of algebra factorization.

- Analytical of the material

The analytical of the material is obtained from interviews to teachers of mathematics of the eight grades of SMPN 9 Muaro Jambi Regency. From the interviews found that in providing the material on parts algebra factorization that the teacher explains more conventional materials. While in teaching the material of algebra factorization requires a special media in the teaching and learning process. This is because of there are many specific terminologies used in the materials of algebra factorization rate so that the learning process requires special media to make the students are more easily to understand the material. Under these conditions the researcher chose the material of algebra factorization in the development of the students' worksheet based on the CTL.

b. Design

At this stage, the design of learning tools such as worksheets that includes the preparation of the product, the preparation of the framework of the students' worksheet, and the preparation of assessment instruments.

c. Development

At this stage there are three activities were conducted: (1) the process of making the students' worksheet, (2) the validation of the students' worksheet by the expert of subject matter, the expert of design, and the expert of media, and (3) the revision of the students' worksheets based on the opinions and recommendations getting from the experts. The result of the development is the assessment or expert validation, and revision of the students' worksheets in order to get it easy to test in the teaching and learning activities.

\section{d. Implementation}

In the implementation stage includes the testing of individual, small group trial, and field trials are carried out in SMP N 9 Muaro Jambi Regency. The test was done 3 times meetings. The data is obtained by individual testing, small group trial evaluation, and evaluation of field trials.

\section{e. Evaluation}

In the evaluation stage the students' worksheets was validated by the expert of subject matter experts, the expert of design, the expert of media, the results of the evaluation of individual testing, the results of the evaluation of small group trial, and the results of the evaluation of field trials. Based on the data analysis it is stated that the students' worksheet is suitable for using as a teaching and learning tool.

2. The quality of the students' worksheet based on the aspect of validity and practicality aspects are as follows:

a. The quality of the students' worksheet based on the aspect of validity according to the expert of subject matter experts, the expert of design, and the expert of media shows that the students' worksheet gets a

"Very Decent" category, Decent, and Very Decent with a percentage of $76.2 \%, 72.4 \%$ and $88.6 \%$. 
b. the quality of the students' worksheet based on the practicality aspects of field trials showed that the students' worksheet has practical value with the percentage of $88.6 \%$ in the category of "Really Practical" for using it as a teaching and learning tool in the classroom.

\section{Suggestion}

Based on the feasibility of the students' worksheet, the weaknesses of the students' worksheet and the limitations of the study the researcher provides some advices of the utilization of the students' worksheet and for further development of the students' worksheet as follows:

1. The students' worksheet which is based on CTL needs to be developed more widely that is the materials presented not only discuss one subject matter, but also covers an expanded material.

2. The students' worksheet needs to be developed further in terms of exercises items. Variations of exercises items could maximize the use of the students' worksheet.

3. For the next researchers the field trials should be carried out more widely. Trials are not only carried out in one school and in one classroom, but also the field trial should be held in more than one school and more than one classroom.

4. For the researchers the students' worksheet assessment should not only be seen from the aspect of validity and its practicality but also it should be seen from the aspect of the effectiveness of the students' worksheet.

5. The students' worksheets which have been developed is expected to be effectively used in Junior High Schools which has similarities characteristics of the field tested school.

\section{References}

[1]. Amri, Sofan. and Iif Khoiru Ahmadi. 2010. Construction Learning Development: Its Effect Mechanism and Practice Curriculum. Jakarta: Performance Library.

[2]. BSNP. 2006. Content Standard for Primary and Secondary Education Unit: Competence Standard and Basic Competence SMP / MTs. Jakarta: BSNP

[3]. MONE. 2008. Teaching Material Development Guide. Jakarta: Ministry of

[4]. Education. DRIs, J. and Tasari. 2011. Mathematical Volume 2 for SMP and MTs Class VIII. Jakarta: Ministry of Education.

[5]. Elaine B. Johnson. Contectual 2009. Teaching and Learning: Making TeachingLearning exciting and Meaningful. Bandung: Kaifa.

[6]. Hasibuan, Idrus. 2014. Learning Model CTL (Contextual Teaching and Learning). Logarithm Vol. II, No. 01

[7]. Hasratuddin. 2014. Learning Math Now and Upcoming Character Based. Didactic Journal of Mathematics, ISSN: 2355-4185, Vol. 1. No. 2. Kemendikbud. 2014. Mathematics. Jakarta: Kemendikbud.

[8]. Lestari, Ika. 2013. Development of Instructional Materials bebasis Competencies: In accordance Education Unit Level Curriculum. Padang: Akademia.

[9]. Matutina, Jemmi Adrian. 2014. Development of Student Worksheet Subject Matter Math Algebra Shape With Contextual Approach For Junior Class VII. Yogyakarta: Yogyakarta University.

[10]. Muslich, Masnur. 2011. SBC and Contextual Competence Based Learning: A Guide for Teachers, Principals and School Supervisors. Jakarta: Earth Literacy.

[11]. Nuharini, Dewi. and Tri Wahyuni. 2008. Mathematical Concepts and Applications. Jakarta: MONE

[12]. Novisa, Nunung. 2014. Development of Student Worksheet Math-Based Contextual Teaching and Learning (CTL) on the Topic of Social Arithmetic in SMP Negeri 1 Kota Bengkulu. Bengkulu: University of Bengkulu.

[13]. Prastowo, Andi. 2015. Free Creative Creating Innovative Instructional Materials: Creating a Learning Method of Interesting and Exciting. Yogyakarta: Diva Press.

[14]. Purbasari, Rohmi Julia. 2012. Android Application Development as Media Learning Mathematics in Three Dimensions Material for High School Students Class X. Journal of Mathematics Education. Vol 1. No. 2.

[15]. Rochmad. 2012. Design Model of Software Development Mathematics Learning.

[16]. Kreano journal, ISSN: 2086-2334. Volume 3 Number 1.

[17]. Rusman. 2014. Models of Learning: Developing Teacher Professionalism. Jakarta: King Grafindo PranadaSabena, Jozua. 2015. Mathematical SMP / MTs. Jakarta: Earth Literacy.

[18]. Salamah, Umi. 2005. Mathematical logic with for Class VIII SMP and MTs. Solo: Triad Pustaka Mandiri.

[19]. Setiawan. 2010. Teaching Materials Training and Development Study Elementary School Mathematics: Mathematics Learning Strategy. Yogyakarta: PPPPTK Mathematics.

[20]. Sudjana. 2005. Statistical Methods. Bandung: Tarsito.

[21]. Sugiyono. 2014. Methods of Administration: Methods include R \& D. Bandung: Alfabeta.

[22]. Susanto, Ahmad. 2013. Learning Theory Teaching in Primary Schools. Jakarta: Kencana Prenada Media Group.

[23]. Tegeh, I Made. et al. 2014. Model Research Development. Yogyakarta: Graha Science.

[24]. Drafting team. 2015. Handbook of Writing Thesis: the Faculty of Education. Jambi. Batanghari University.

[25]. Trianto. 2007. Model Integrated Learning in Theory and Practice. Jakarta: Achievements Reader Publisher.

[26]. Widoyoko, Eko Putro. 2015. Learning Program Evaluation: A Practical Guide For Teachers and Educators Candidate. Yogyakarta: Student Library. 